\title{
KONSEP DESAIN MALL EKSIBISI UNTUK STARTUP: INTEGRASI ANTAR RUANG DIGITAL DAN FISIK
}

\author{
Evian Putra Setiawan ${ }^{1)}$, Fermanto Lianto ${ }^{2)}$ \\ 1)Program Studi S1 Arsitektur, Fakultas Teknik, Universitas Tarumanagara, evianputra@gmail.com \\ 2) Program Studi S1 Arsitektur, Fakultas Teknik, Universitas Tarumanagara, fermantol@ft.untar.ac.id
}

\begin{abstract}
Abstrak
Pertumbuhan ecommerce khususnya di Indonesia semakin meningkat. Generasi milenial yang menjadi motor utama perekonomian merupakan pengguna terbesar, baik menjadi penjual maupun pembeli. Di dalam online shop, seorang pembeli langsung diarahkan ke dalam halaman utama yang langsung mengarahkan ke halaman kategori barang yang ingin dilihat secara cepat. Meski sudah hadir online shop, mall fisik pun tetap dibutuhkan. Penjual membutuhkan sebuah tempat untuk memamerkan dan mengenalkan produk barunya agar dikenal masyarakat dan dipercaya untuk dibeli melalui online shop, sedangkan pembeli juga datang ke mall fisik karena ingin mengetahui kualitas barang yang akan dibeli, serta menginginkan experience yang baru dan berbeda. Untuk mempelajari pola perilaku pengguna online shop, maka digunakan metode pattern language, sehingga didapatkan bahwa pola pengguna pada saat berbelanja adalah terpusat, sedangkan pola pengguna mall fisik adalah linear. Untuk menjawab tantangan kesejamanan, maka dihasilkan konsep desain mall eksibisi startup dengan integrasi antar ruang digital dan fisik yang menggunakan pola terpusat sebagai pola sirkulasi di dalam bangunan.
\end{abstract}

Kata kunci: Fisik; Mall Eksibisi; Milenial; Ruang Digital; Startup

\begin{abstract}
The growth of ecommerce in Indonesia especially is getting vast. The millennial generation which has been the prime generator of the economics shares the most user, either becomes the seller or the buyer. In online shop, a user is immediately directed to the main page that also directs to the category of a wanted item in less than a second. Although there have been online malls, physical malls are also considered as neccesary for most people. Sellers need space where they can storytell and introduce their newly-invented products to get recognition so people are convinced to buy online. Buyers also come to physical malls to experience things they are not able to get online, meanwhile buyers also come to physical malls to inspect the quality of the product. Through a study of online shoppers behavior with Pattern Language method, we can conclude that online shoppers' pattern are centralized, and physical mall shoppers' pattern are linear instead. Therefore, the design concept of startup exhibition mall with integration between digital and physical space is created by applying centralized pattern as the building circulation to solve this matter.
\end{abstract}

Keywords: Digital Space; Exhibition Mall; Millennials; Physical; Startup

\section{PENDAhuluAN}

Dewasa ini, pertumbuhan e-commerce di Indonesia semakin meningkat. Startup, perusahaan yang baru dirintis, mencoba memperkenalkan produk-produk dengan inovasi baru dan daya tarik tinggi. Mereka biasanya memilih untuk menjual produknya melalui platform online, karena lebih mudah dan tidak mengeluarkan biaya untuk menyewa tempat yang mahal di shopping mall. Namun kendalanya, produk-produk ini perlu dipamerkan untuk diperkenalkan kepada masyarakat. Mereka membutuhkan sarana dan ruang fisik untuk mempertemukan dan memperkenalkan produk mereka ke orang-orang lain yang menjadi target konsumen, serta menjual produknya.

Produk-produk startup harus diperkenalkan secara fisik untuk meyakinkan pembeli. Karena produk yang dijual cenderung baru dan inovatif, orang yang melihat produk startup cenderung 
mempertanyakan keberhasilan idenya, serta kualitas produknya. Beberapa jenis benda tidak dapat dinikmati nilainya secara maksimall tanpa adanya kehadiran fisik seperti kerajinan tangan, hasil desain produk, pakaian, dan furniture. Dengan menyewa tenant di mall, biaya yang harus dikeluarkan oleh sebuah perusahaan startup yang baru dirintis dirasa memberatkan. Maka, tren yang sudah ada sekarang adalah menyewa booth kecil pada suatu acara yang diadakan oleh mall. Namun, acara tersebut hanya berlangsung dalam kurun waktu tertentu.

Studi mengatakan bahwa online retail akan berkembang terus dan mengambil alih peran mall fisik. Namun, mall yang memberikan experience tersendiri bagi pengunjung masih sangat diminati. Generasi muda masih memilih menggunakan keduanya dalam berbelanja. Pembeli tetap datang ke mall fisik untuk melihat dan memegang barang, serta melakukan hal lainnya (Bird, 2018).

Baik mall digital maupun mall fisik memiliki kelebihan dan kekurangannya masing-masing. Oleh sebab itu, untuk menanggapi fakta dan menjawab permasalahan tersebut, maka diperlukan konsep desain mall eksibisi startup dengan integrasi antar ruang digital dan fisik.

\section{KAJIAN LITERATUR}

\section{Sejarah Mall}

Mall merupakan sebuah bangunan besar atau kumpulan bangunan yang terdiri dari tokotoko dari banyak macam barang (Smith, 2009). Tipologi mall dari zaman ke zaman ditentukan oleh perubahan budaya. Ketika budaya konsumerisme marak di tahun 1700an, mall mulai beroperasi. Permulaan mall berawal dari terbentuknya shopping arcade yang merupakan penghubung antar bangunan yang diisi sebagai sebuah wadah untuk melakukan berbagai kegiatan termasuk kegiatan ekonomi. Di tahun 1800an, terjadi revolusi industri. Kendaraan pribadi mulai dimiliki masyarakat luas, sehingga mall memiliki ruang untuk parkir yang luas. Warga mulai memadati pinggiran kota di tahun 1900an, sehingga mall dibuat dengan skala yang besar untuk menjangkau seluruh warga. Dari sini muncul istilah dumbbell and anchor tenant, di mana tujuannya adalah untuk memfokuskan dan mengarahkan alur pengunjung yang padat. Perjalanan persaingan mall semakin ketat, hingga sekarang mall terus berlombalomba untuk memberikan fitur-fitur kreatif sebagai daya jual. Saat ini, telah terjadi perubahan budaya yang besar, yaitu peralihan media fisik ke dalam digital. Dari perubahan ini tentu akan ada tipologi mall yang baru (Lee, 2015).

Dari dulu, orang sudah membeli produk melalui katalog, kemudian memsan dan dikirim barangnya beberapa hari kemudian. Hingga di tahun 1993, ketika bermuncullan shopping mall, katalog mulai ditinggalkan masyarakat karena kendala waktu yang lama dan barang yang datang tidak sesuai dengan ekspektasinya. Dengan hadirnya shopping mall, orang dapat langsung melihat barangnya dan membayar, kemudian dibawa pulang. Namun, terdapat beberapa kendala, yaitu waktu yang lama untuk memilih barang di dalam satu mall yang besar, serta kesulitan untuk membawa barang sendiri. Sekarang, orang mulai kembali ke katalog lagi karena hal tersebut. Mereka memilih untuk berbelanja online untuk barang-barang tertentu. Namun, kendalanya terdapat di wujud barang yang tidak bisa dilihat secara langsung dan dicoba. Kendala ini harus dicarikan solusi. Menurutnya pula, kita sekarang berada di dunia yang berorientasi pada experience. Generasi Millennial adalah penggerak utama orientasi ini, di mana orang mulai mengunjungi tempat-tempat yang memiliki experience tidak biasa dan dipamerkan di internet (Linton, 2017). 

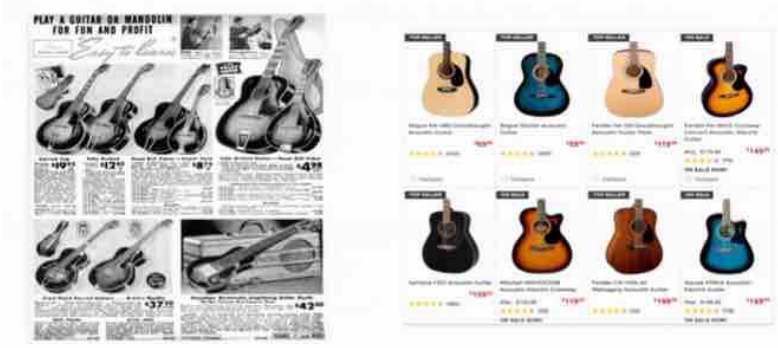

Gambar 1. Perbandingan Sears Catalogue lama dengan Online Mall saat ini.

Sumber: www.youtube.com/watch?v=nyAcQuFWRuU

\section{Fenomena Gadget pada Generasi Millennial}

Salah satu fenomena penting proses globalisasi telah melahirkan generasi gadget, istilah yang digunakan untuk menandai munculnya generasi millennial. Gadget sebenarnya lebih pas diartikan dengan peralatan, sehingga generasi gadget dimaksudkan dengan generasi yang dalam kehidupannya selalu bersinggungan dengan yang namanya peralatan yang mengandung unsur teknologi informasi. Jadi seolah-olah berbagai peralatan tersebut telah menjadi bagian yang tak terpisahkan dari kehidupan mereka. Seolah- olah berbagai alat high-technology telah menjadi bagian penting dalam kehidupannya (Zuhal, 2000; Naisbitt, 2002).

Milenial adalah generasi yang berada di dua dunia: satu kaki di dunia lama dan satu kaki di dunia baru; menginjak dua dunia yang berbeda. Generasi Millennial merasakan adanya Hectic Period pada saat 9/11 Attack, membuat generasi millennial lebih cepat tanggap dan memiliki sifat -sifat entrepreneurial terbanyak dibandingkan dengan generasi-generasi lainnya (Burstein, 2012).

\section{Perusahaan Startup}

Perusahaan startup adalah usaha entrepreneur yang baru diluncurkan, bertumbuh cepat yang menyasar untuk memasuki pasar dengan membuat model bisnis produk-produk, layanan, dan platform inovatif. Perusahaan startup biasanya beroperasi dengan modal yang sangat terbatas untuk menemukan model yang berhasil ke ranah dunia. Pendiri startup biasanya melakukan riset sedalam pengetahuan ide mereka, teknologi, dan potensi komersial. Tim pendiri startup haruslah sebuah grup yang berisi oleh orang-orang inovatif, selalu mencari pasar baru untuk menguji implementasi ide-ide mereka, seefisien dana yang bisa dikeluarkan (DeGroat, 2016).

\section{Penerapan Teknologi pada Mall}

Terdapat teknologi-teknologi yang dapat dimanfaatkan dalam berjalannya shopping mall di masa kini.

\section{Teknologi Beacon}

Teknologi ini menggunakan teknologi Bluetooth Low Energy (BLE) untuk mengetahui lokasi pembeli dan memberikan pesan sesuai dengan waktu dan tempatnya. Prosesnya seperti RFID, tetapi teknologi ini lebih privat. Dari iklan di tahun 2015, penjualannya sudah mencapai 4 milyar dollar AS (Maycotte, 2015). 


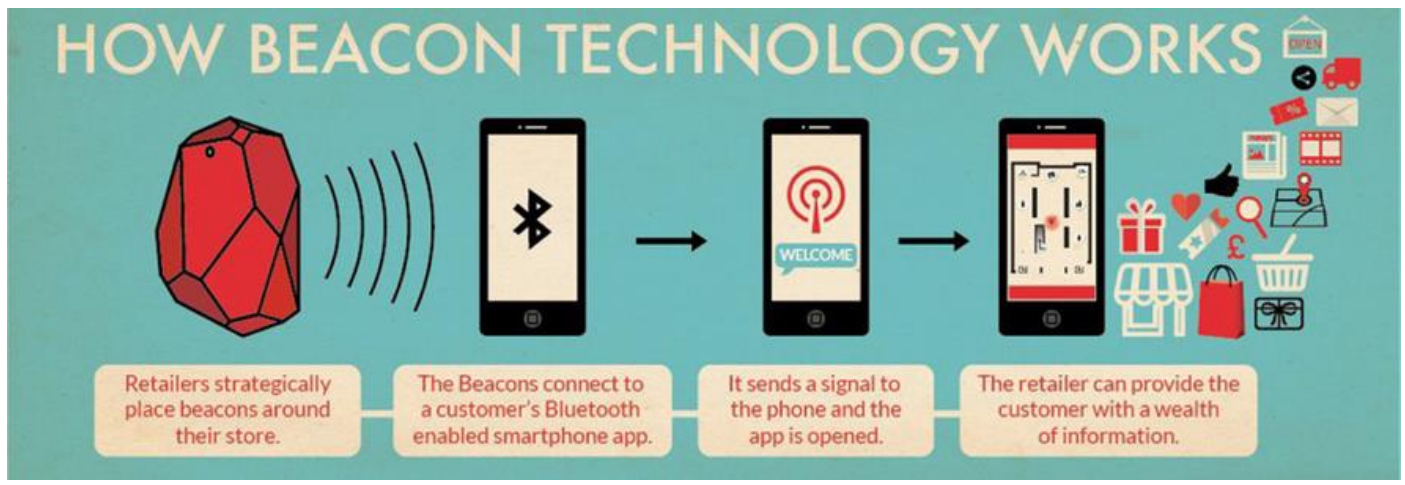

Gambar 2. Teknologi Beacon

Sumber: https://www.360technosoft.com/blog/how-do-beacon-technology-works

\section{Pembayaran Mobile}

Ada banyak cara untuk membuat pembayaran menggunakan perangkat mobile, contohnya, dompet digital, pembayaran melalui internet dan juga SMS. Ini membuat berbelanja online lebih cepat dan prosesnya lebih mulus. Ada juga alat-alat pemindai yang dapat digunakan untuk memotret gambar atau memindai produk untuk memesan kembali. Ini termasuk salah satu contoh penggabungan fisik dengan online ketika berbelanja. Pelanggan dapat melihat produk dengan mata mereka sendiri, mencobanya, tetapi tidak kehilangan pengalaman berbelanjanya (Sorensen, 2018).

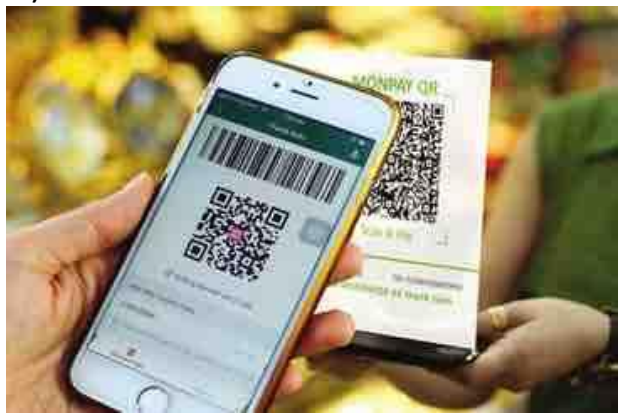

Gambar 3. Pembayaran menggunakan Mobile

Sumber: www.vir.com.vn/mobile-payment-the-next-big-thing-57602.html

\section{Toko Virtual}

Tesco Homeplus meluncurkan Virtual Subway store di Korea Selatan yang mengijinkan pembeli untuk memindai barang-barang keperluan yang akan dipesan ke rumah mereka dan diantar dalam waktu kurang dari satu hari. Teknologi ini mulai mempertanyakan kebutuhan shopping space yang tipikal seperti dibayangkan oleh banyak orang. Sekarang, Display dapat secara teknis diminimallisir menggunakan panel-panel LED seperti pada gambar 4 (Bonasio, 2018).

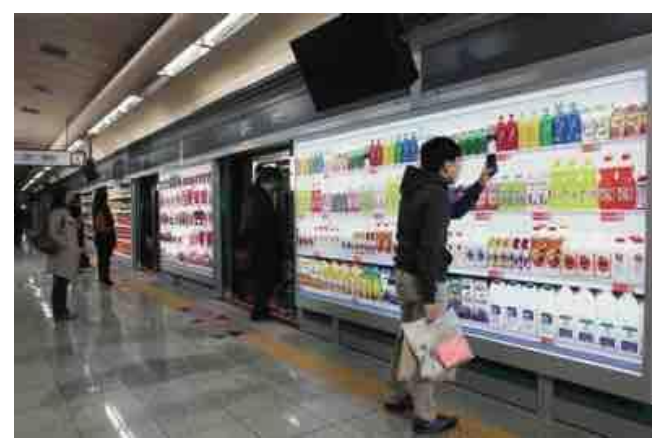

Gambar 4. Toko Virtual

Sumber: www.zdnet.com/article/virtual-store-enables-commuters-in-seoul-to-multitask-whilewaiting/ 


\section{METODE}

Metode yang penulis gunakan dalam perancangan proyek ini adalah "Pattern Language" yang dicetuskan oleh Christopher Alexander dalam bukunya, "A Pattern Language, 1977". Dalam bukunya, Alexander mengembangkan Bahasa pola yang dapat diterapkan secara universal untuk memecahkan pola-pola dari event-event tertentu. Menurut Alexander, sebuah pembangunan adalah proses yang tidak berujung di mana hasil terbaik didapat ketika kita sebagai perancang dapat menemukan pattern pengguna bangunannya (Alexander, C. et al., 1977).

\section{DISKUSI DAN HASIL}

Analisis dimulai dari mencermati pattern yang dilakukan oleh pengguna online shop. Pengguna online shop ketika memasuki situs online marketplace akan diarahkan langsung ke halaman utama (main page), di mana pada halaman tersebut terdapat semua info tentang produk yang dijual. Kemudian, pengguna akan melakukan klik pada gambar yang dituju dan diarahkan ke halaman kategori, kemudian diarahkan ke halaman barang yang diinginkan.

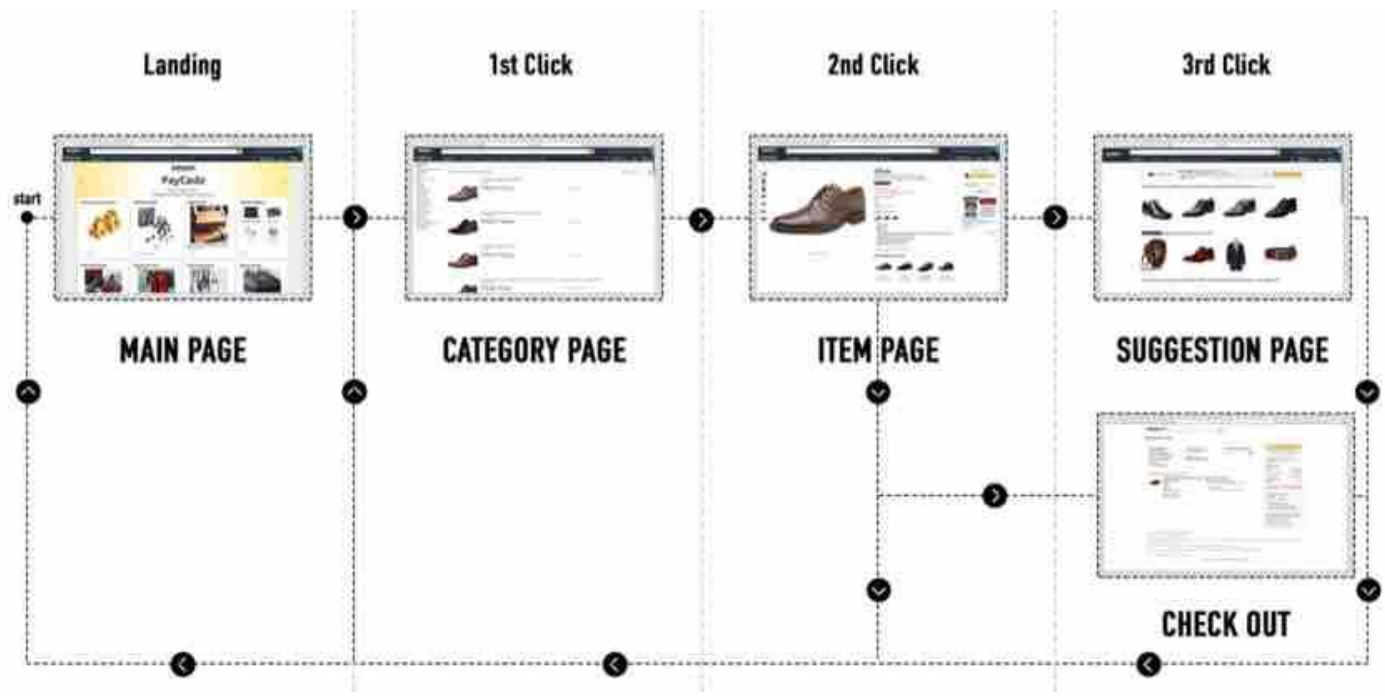

Gambar 4. Online Shopping Pattern Behavior

Sumber: Penulis, 2019

Pola ini memberikan pengguna kemudahan bagi pengguna dalam mencari barang dan juga menemukan barang-barang lain yang mereka butuhkan. Proses ini memberikan kemudahan dan juga mempersingkat waktu, karena semua barang yang dicari dapat didapatkan hanya dengan memasuki halaman utama sebagai pusatnya. Pola ini dapat disebut sebagai pola terpusat.

Lain halnya dengan pattern yang didapati pada pelanggan yang datang ke mall fisik. Pelanggan datang, melihat barang pada satu toko, kemudian jalan secara linear dari satu toko ke satu toko lainnya.

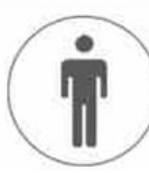

Pembeli

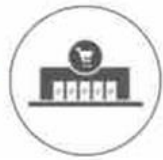

Mall

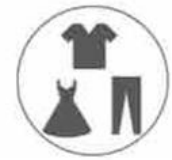

Melihat-lihat

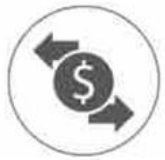

Transaksi

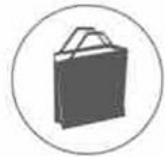

Produk

Gambar 5. Physical Shopping Pattern Behavior

Sumber: Penulis, 2019 
Pola yang terjadi pada sistem konvensional adalah linear. Pola ini sudah tidak relevan lagi di jaman ini, karena pelanggan menuntut kecepatan proses seperti yang terjadi pada platform online. Pada proses ini, setiap orang harus melewati toko satu demi satu hingga ia menemukan barang yang ingin dibeli.

Analisis zonasi dan pola sirkulasi didasarkan pada 6 buah kategori yang diambil dari kategori barang dengan komoditas ekspor tertinggi menurut badan ekonomi kreatif yang menunjukkan bahwa kategori tersebut sangat diminati. Adapun kategori tersebut adalah:

- Baju

- Sepatu

- Tas

- Karya Seni Desain Produk

- Furniture

- Karya kerajinan tangan

(Syahid, 2017).

Keenam kategori tersebut kemudian dilakukan simulasi pada situs online untuk menemukan hubungan pola yang langsung, tidak langsung, maupun tidak berhubungan. Kemudian, hubungan antar kategori diimplementasikan ke dalam bangunan. Dengan model pola terpusat, dapat ditentukan bahwa halaman utama online marketplace dapat diaplikasikan ke bangunan utama (main building). Bagian-bagian bangunan yang lebih kecil merupakan bangunan kategori, sehingga barang yang didisplay merupakan halaman barang (gambar 6).

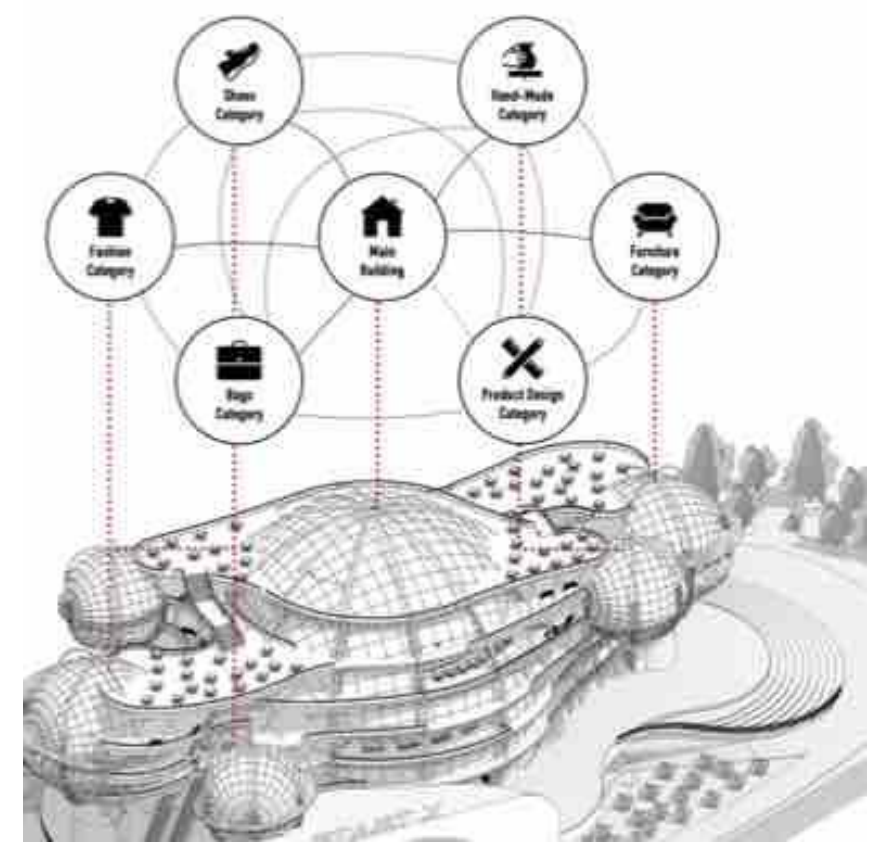

Gambar 6. Usulan Online Shopping Pattern Conncetion di dalam bangunan

Sumber: Penulis, 2019

Dengan bantuan teknologi, pengunjung dapat mendapatkan efisiensi dan efektifitas seperti yang didapatkan pada online shop. Ketika pengunjung masuk, lokasi setiap pengunjung diidentifikasi oleh perangkat Beacon. Pengunjung pertama kali menginjak lokasi main exhibition yang berada di bangunan utama. Teknologi Beacon dapat menganalisa ketertarikan pengunjung tersebut melalui durasi titik diam yang terpanjang. Contohnya, jika seseorang berdiri lama di depan booth sepatu, maka teknologi Beacon menyimpulkan bahwa pengunjung memiliki ketertarikan pada sepatu, atau ingin membeli sepatu. Dari data tersebut, teknologi YITU yang merupakan program penganalisa Beacon menentukan ke mana pengunjung tersebut harus diarahkan secara tepat. Pada kasus ini, maka pengunjung diarahkan ke zona 
eksibisi sepatu. Bentuk massa bangunan lebih baik melingkar sehingga tidak memiliki sudutsudut yang menghalangi alur pengunjung berjalan dari satu titik lokasi ke titik lokasi lainnya (Lihat Gambar 7, 8).

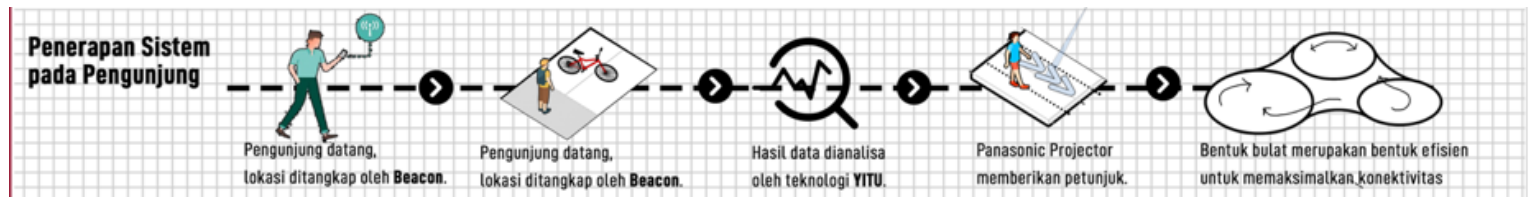

Gambar 7. Penerapan Teknologi pada Sistem Alur Pengunjung

Sumber: Penulis, 2019

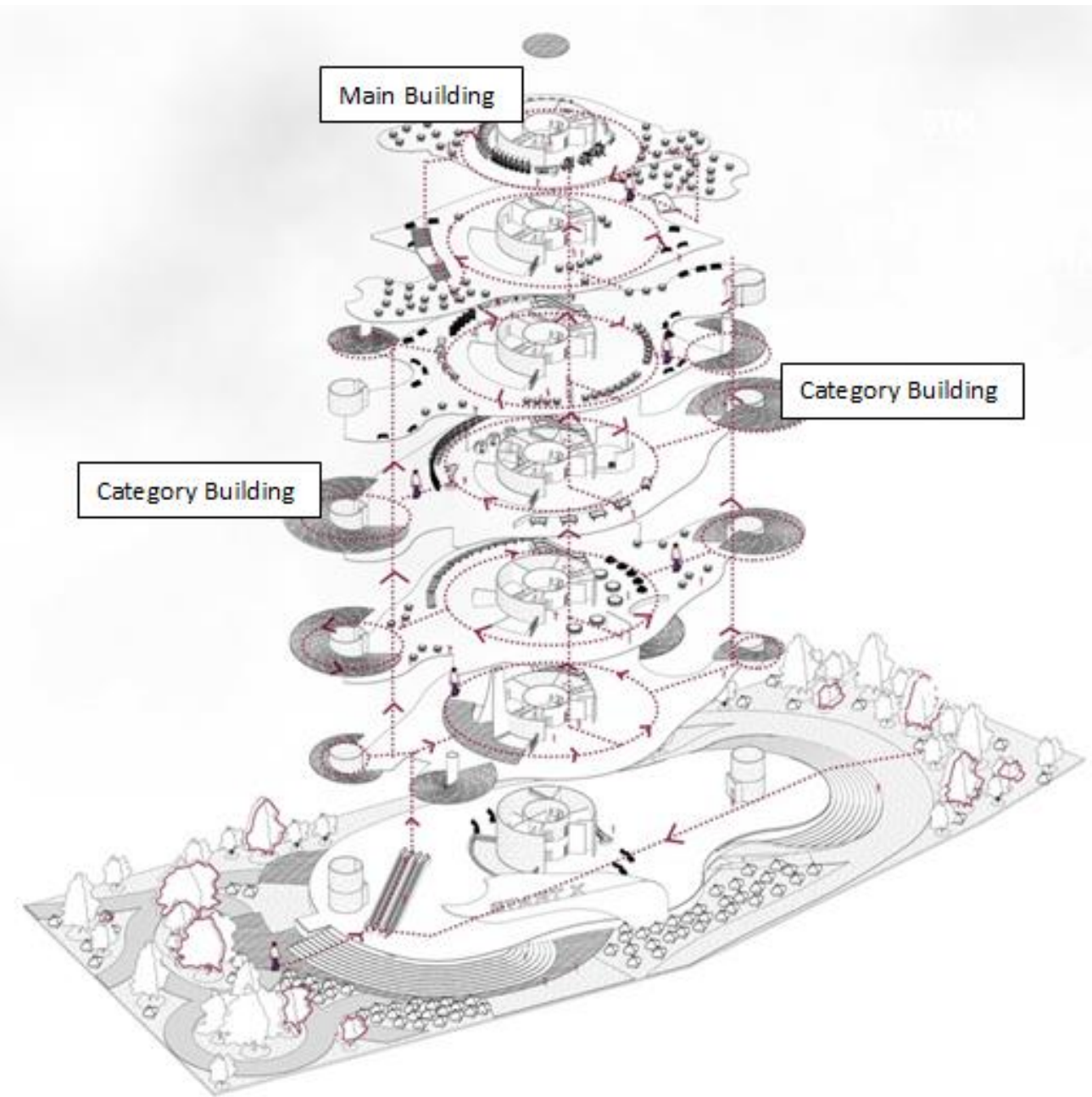

Gambar 8. Usulan Alur pengunjung Startup Exhibition Mall

Sumber: Penulis, 2019

\section{KESIMPULAN DAN SARAN}

Tipologi bangunan pusat perbelanjaan yang ada sekarang kurang sesuai dengan jaman karena memiliki pattern linear yang kurang efektif untuk sebuah eksibisi. Tipologi mall yang lebih sesuai untuk menjawab persoalan milenial dan startup adalah mall pattern terpusat, karena sudah terpengaruh oleh pattern yang dimiliki oleh online marketplace dan memiliki lebih cocok untuk eksibisi. Dengan pattern ini, pengunjung dapat lebih efektif dan efisien dalam berbelanja karena dapat melihat barang yang dituju secara cepat dan juga lebih menguntungkan bagi pemilik usaha startup karena terdiri dari unit-unit kecil yang memang disewakan khusus untuk eksibisi produk. 


\section{REFERENSI}

Alexander, C., Ishikawa, S., Silverstein, M., Jacobson, M., Fiksdahl-King, I., \& Shlomo, A. (1977). A pattern language: Towns, buildings, construction. London: Oxford University Press.

Bird, Jon. (2018). The Future of the Shopping Mall Is Not About Shopping. Dikutip pada tanggal 12 Februari 2019 dari https://www.forbes.com/sites/jonbird1/2018/06/17/the-future-ofthe-shopping-mall-is-not-about-shopping/\#410fb1f15cf2

Bonasio, Alice. (2018). Will Virtual Shopping Malls Save Retailers. Dikutip pada tanggal 4 Maret 2019 dari https://www.forbes.com/sites/alicebonasio/2018/07/22/will-virtual-shoppingmalls-save-retailers/\#1dd2907c6232

Burstein, David. (Pembicara). (2012). Fast Future, The Rise of the Millennial Generation [Berkas Video]. Diambil dari https://www.youtube.com/watch?v=WMPWxUduPI4

DeGroat, T. J. (2018). Data Visualization Trends for Millennials. Dikutip pada tanggal 11 Februari 2019 dari https://www.springboard.com/blog/data-visualization-trends-formillennials/

Lee, Ensam, (2015). The Architecture of Consumption: A New Transient Shopping Space. [Architecture Thesis]. 300. https://surface.syr.edu/architecture_tpreps/300

Linton, Morgan. (Pembicara). (2017). The Future of Commerce, From Ancient Rome to Virtual Reality [Berkas Video]. Diambil dari https://www.youtube.com/watch?v=nyAcQuFWRuU

Maycotte, H. (2015). Beacon Technology: The Where, What, Who, How and Why. Dikutip pada tanggal 5 Maret 2019 dari https://www.forbes.com/sites/homaycotte/2015/09/01/beacontechnology-the-what-who-how-why-and-where/\#279940ab1aaf

Naisbitt, J. (2002). High Tech High Touch. Jakarta: Pustaka Mizan.

Smith, John. (2009). Encyclopaedia Britannica, 8th ed., s.v. "Internet." Chicago: Encyclopaedia Britannica.

Syahid. (2018). Ada 16 subsektor ekonomi kreatif, apa sajakah itu?. Dikutip pada tanggal 10 Mei 2019 dari https://www.elshinta.com/news/154365/2018/08/30/ada-16-subsektorekonomi-kreatif-apa-sajakah-itu

Sorensen, Emily. (2018). Different Types of Mobile Payment Explained. https://www.mobiletransaction.org/different-types-of-mobile-payments/

Zuhal. (2000). Visi Iptek Memasuki Milenium III. Jakarta: Penerbit Universitas Indonesia (UIPress). 